\title{
NiaA, the structural nitrate reductase gene of Phytophthora infestans: isolation, characterization and expression analysis in Aspergillus nidulans
}

Received: 21 July 1994 / 14 September 1994

\begin{abstract}
The nitrate reductase (NR) gene niaA of the oomycete Phytophthora infestans was selected from a gene library by heterologous hybridization. NiaA occurs as a single-copy gene and its expression is regulated by the nitrogen source. The nucleotide sequence of niaA was determined and comparison of the deduced amino-acid sequence of 902 residues with NRs of higher fungi and plants revealed a significant homology, particularly within the three cofactor-binding domains for molybdenum, heme and FAD. The $P$. infestans niaA gene was used as a model gene to test whether oomycete genes are functional in the ascomycete Aspergillus nidulans, a fungus which is highly accessible for molecular genetic studies. The complete niaA gene was stably integrated into the genome of a nia deletion mutant of $A$. nidulans. However, transformants containing one or more copies of the niaA gene were not able to complement the nia mutant. This suggests that there is no functional expression of the introduced niaA gene in A. nidulans. In addition, the activity of two other oomycete gene promoters was analyzed in a transient expression assay. Plasmids containing chimaeric genes with the promoter of the $P$. infestans ubiquitin gene $u b i 3 R$, or the Bremia lactucae ham 34 gene, fused to the coding sequence of the Escherichia coli $\beta$-glucuronidase (GUS) reporter gene, were transferred to A. nidulans protoplasts. No significant GUS activity was detectable indicating that the $u b i 3 R$ and ham 34 promoters are not active in A. nidulans. Apparently, the regulatory sequences which are sufficient for gene activation in oomycetes are not functional in the ascomycete $A$. nidulans.
\end{abstract}

C. M. J. Pieterse' - J. van’t Klooster - G. C. M. van den Berg-Velthuis F. Govers $(\bowtie)$

Department of Phytopathology,

Wageningen Agricultural University, Binnenhaven 9,

NL-6709 PD Wageningen, The Netherlands

'Present address: Department of Plant Ecology and Evolutionary Biology, Section Phytopathology, Utrecht University, P.O. Box 800.84, NL-3508 TB Utrecht, The Netherlands

Communicated by P. J. G. M. de Wit
Key words Phytophthora infestans

Nitrate reductase gene $\cdot$ Transformation - Oomycete

\section{Introduction}

The oomycete Phytophthora infestans (Mont.) de Bary is a destructive pathogen causing late blight on potato, tomato and several other Solanaceae. The oomycete class of fungi contains many economically important plant pathogens. To study the molecular and cellular processes involved in the interaction of oomycetous plant pathogens with their host plants, characterization of pathogenicity genes is an important step. We have isolated several $P$. infestans genes whose gene products might have a role in pathogenicity (Pieterse et al. 1991, 1993a,b, 1994). To study the function and regulation of these genes, DNA transformation is an essential tool. At present, while transformation of P. infestans is an established procedure (Judelson et al. 1991, 1993) the transformation efficiency is relatively low and, compared to some ascomycetes, P. infestans is slow growing. Moreover, for successful transformation, regulatory sequences of oomycete origin seem to be crucial. Regulatory sequences from genes of non-oomycetes, including ascomycete and basidiomycete fungi, are not functional in P. infestans (Judelson et al. 1992). In the present study we tested, in two different ways, whether oomycete regulatory sequences are functional in the ascomycete Aspergillus nidulans. If so, this would facilitate further molecular genetic studies on oomycete genes, such as promoter analysis or complementation experiments.

In this paper, we describe the isolation and characterization of the $P$. infestans nitrate reductase (NR)-encoding gene niaA. The niaA gene was subsequently used to test if oomycete regulatory sequences function in A. nidulans. This was done by transforming the $P$. infestans niaA gene to a A. nidulans nia mutant and analyzing the transformants for functional complementation of the NR deficiency. It has been shown that NR deficiency in several filamentous fungi, including some plant pathogens, 
can be complemented by the introduction of heterologous NR genes (Daboussi et al. 1989; Whitehead et al. 1989; Unkles et al. 1989a,b). In a second approach to test oomycete regulatory sequences in a non-oomycete we used constructs containing promoter-GUS fusions. The activity of the promoters of the $P$. infestans ubiquitin gene $u b i 3 R$ (Pieterse et al. 1991) and the Bremia lactucae ham 34 gene (Judelson and Michelmore 1990) was analyzed by measuring GUS activity in transient expression assays in A. nidulans.

\section{Material and methods}

Culturing of $\mathrm{P}$. infestans and A. nidulans. P. infestans strain 88069 was grown as described previously (Pieterse et al. 1991). The standard media and growth conditions for A. nidulans described by Cove (1966) were used.

Isolation and sequencing of the $\mathrm{P}$. infestans niaA gene. A $\lambda$ EMBL3 genomic library of $P$. infestans was constructed as described previously (Pieterse et al. 1991). In total, $8 \times 10^{4}$ recombinant plaques comprising six times the $P$. infestans genome were plated in duplicate. Replica filters were hybridized for $16 \mathrm{~h}$ at low stringency $\left(58^{\circ} \mathrm{C}\right)$ in a hybridization mix containing $5 \times \mathrm{SSC}(750 \mathrm{mM} \mathrm{NaCl}, 75 \mathrm{mM}$ $\mathrm{Na}_{3}$-citrate), $5 \times$ Denhardt's solution $[0.1 \%(\mathrm{w} / \mathrm{v})$ Ficoll, $0.1 \%(\mathrm{w} / \mathrm{v})$ polyvinylpyrrolidone, $0.1 \%(\mathrm{w} / \mathrm{v})$ BSA (fraction V)], $0.5 \%$ SDS and $100 \mu \mathrm{g} / \mathrm{ml}$ of calf thymus DNA. As a probe the $1.5-\mathrm{kb} \mathrm{BamHI} / \mathrm{Bg} / \mathrm{II}-$ fragment from pSTA10 was used, which covers a large part of the coding region of the NR gene (niaD) of A. niger (Unkles et al. 1989a). This probe was labelled with $\left[\alpha-{ }^{32} \mathrm{P}\right] \mathrm{dATP}$ by random primer labelling as described by Feinberg and Vogelstein (1983). Filters were washed in $2 \times \mathrm{SSC} / 0.5 \% \mathrm{SDS}$ at $58^{\circ} \mathrm{C}$ and exposed to Kodak X-OMAT $\mathrm{S}$ film. Positive plaques were purified by a second round of hybridization. DNA restriction analyses and subcloning of fragments from the selected lambda clones was performed according to standard procedures (Sambrook et al. 1989). Sequencing of DNA fragments was done on double-stranded DNA by the dideoxy chain-termination method (Sanger et al. 1977) using the Multiwell Microtitre Plate Sequencing System (Amersham) and $\left[\alpha-{ }^{35}\right.$ S $]$ dATP as a label. Analyses of the sequence data and alignment of the amino-acid sequences were performed using the Sequence Analysis Software Package, Version 7.1, of the Genetics Computer Group (GCG) of the University of Wisconsin (Devereux et al. 1984).

Genomic Southern-blot analysis. Genomic DNA of P. infestans strain 88069 and A. nidulans strain ANGW1103 was isolated as described by Pieterse et al. (1991). DNA was digested with various restriction enzymes and size-separated on $0.7 \%$ agarose/TBE gels. Following electrophoresis, DNA was blotted onto Hybond- $\mathrm{N}^{+}$membranes (Amersham) by capillary transfer (Sambrook et al. 1989) and hybridized at high stringency $\left(65^{\circ} \mathrm{C}\right)$ in a hybridization mixture containing $0.5 \mathrm{M} \mathrm{Na}_{2} \mathrm{HPO}_{4} / \mathrm{NaH}_{2} \mathrm{PO}_{4}(\mathrm{pH} 7.2), 7 \%$ SDS and $1 \mathrm{mM}$ EDTA. Probes were labelled with $\left[\alpha^{32}\right.$ P]dATP by random primer labelling (Feinberg and Vogelstein 1983). Blots were washed in $0.1 \times \mathrm{SSC} / 0.1 \% \mathrm{SDS}$ at $65^{\circ} \mathrm{C}$ and exposed to Kodak X-OMAT AR film.

RNA isolation and northern-blot analysis. Total RNA was isolated from a $P$. infestans mycelium grown in Henniger synthetic medium (Henniger 1959) with (1) $48 \mathrm{mM} \mathrm{NaNO} 3$ and no ammonium or (2) $48 \mathrm{mM}\left(\mathrm{NH}_{4}\right)_{2} \mathrm{SO}_{4}$ and no nitrate. The RNA isolation was performed as previously described (Pieterse et al. 1991). For northern-blot analysis, $15 \mu \mathrm{g}$ of total RNA was denatured in DMSO/glyoxal and electrophoresed on a $1.4 \%$ agarose gel (Sambrook et al. 1989). Following electrophoresis, the RNA was blotted onto a Hybond- ${ }^{+}$membrane (Amersham) by capillary transfer and hybridized at high stringency $\left(65^{\circ} \mathrm{C}\right)$ as described above using the random primer-labelled $2.2-\mathrm{kb} \mathrm{NcoI}$-fragment from $\mathrm{pNiaA}-\mathrm{S}$ as a probe. The blot was washed in $0.5 \times \mathrm{SSC} / 0.1 \% \mathrm{SDS}$ at $65^{\circ} \mathrm{C}$ and exposed to Kodak X-Omat $\mathrm{AR}$ film. After de-probing, the blot was rehybridized with the $2.8-\mathrm{kb}$ Pst $\mathrm{I}$-insert from pSTA 31 containing the constitutively expressed actin (actA) gene of $P$. infestans (Unkles et al. 1991).

Integrative transformation of A. nidulans. The plasmids pSTA10 (Unkles et al. 1989a) and pNiaA-H, containing the NR genes of $A$. niger and $P$. infestans, respectively, were transformed to $A$. nidulans as described by Wernars et al. (1985). As A. nidulans recipient strain the nia deletion mutant ANGW1103, which is an $\mathrm{arg}^{+}$derivative of strain SAA1017 (yA2, argB2, niaD26) (T. Goossen, personal communication), was used. The nia phenotype of SAA1017 is due to a deletion in the niaD gene (Tomsett and Cove 1979). $\mathrm{CaCl}_{2}$-PEG-mediated transformation was performed using $2 \times 10^{7}$ protoplasts and 5 $\mu \mathrm{g}$ of plasmid DNA. Transformants were selected on minimal medium containing $50 \mathrm{mM} \mathrm{NaNO}_{3}$ as a sole nitrogen source. For cotransformation, $2 \times 10^{7}$ protoplasts were transformed with a mixture of $5 \mu \mathrm{g}$ pAN8-1 and $20 \mu \mathrm{g}$ pSTA10 or pNiaA-H, respectively. Integration of plasmid pAN8-1 confers resistance to phleomycin (Mattern and Punt 1988). Transformants were selected on minimal medium containing $60 \mu \mathrm{g} / \mathrm{ml}$ phleomycin. The percentage of co-transformation was determined by transferring the transformants to minimal medium containing $50 \mathrm{mM} \mathrm{NaNO}_{3}$ as a sole nitrogen source.

Transient expression assay. For the transient expression assays, in which the activity of various gene promoters was determined, transformation of A. nidulans strain ANGW1103 was performed as described above using $2 \times 10^{7}$ protoplasts and $5 \mu \mathrm{g}$ of plasmid DNA. The plasmids used are listed in Table 2. After transformation, the protoplasts were allowed to regenerate for $4 \mathrm{~h}$ at $30^{\circ} \mathrm{C}$ in MMS medium (Wernars et al. 1985). Regenerated protoplasts were collected by centrifugation $(5 \mathrm{~min}$ at $10000 \mathrm{~g}$ ) and homogenized in an equal volume of GUS-extraction buffer $\left(50 \mathrm{mM} \mathrm{NaPO}_{4}, 10 \mathrm{mM}\right.$ $\mathrm{Na}_{2}$ EDTA, $0.1 \%$ Triton X-100, $10 \%$ N-laurylsarcosine, $10 \mathrm{mM} \beta$ mercaptoethanol, $\mathrm{pH} 7.0$ ). After an incubation of $30 \mathrm{~min}$ on ice, the homogenate was cleared by centrifugation $(2 \mathrm{~min}$ at $10000 \mathrm{~g}$ ) and protein concentrations were determined by the Biorad Protein Assay. GUS analyses were performed in a fluorometric assay as described by Gallagher (1992) using $5 \mu \mathrm{g}$ of protein per assay and 4-methylumbelliferyl $\beta$-glucuronide ( $1 \mathrm{mM}$ ) as a substrate.

\section{Results}

Isolation of the P. infestans niaA gene

To isolate the gene encoding the nitrate reductase (NR) apoenzyme of $P$. infestans, a genomic library was screened under low-stringency conditions using a part of the coding region of the $A$. niger niaD gene as a probe. Initially eight clones were selected of which four were still positive in the second round of hybridization. Restriction-fragment analysis revealed no homology in restriction patterns indicating that the four clones were not overlapping. A Southern blot containing digested DNA of the four $\lambda$ clones was hybridized with the same $A$. niger niaD probe and the hybridizing fragments were subcloned and partially sequenced. Several fragments from $\lambda$ nia 2 showed significant sequence homology with parts of the A. niger niaD nt sequence whereas the sequenced fragments of the other three clones shared no homology at all. The latter were considered to be false positives. A partial restriction map of $\lambda$ nia 2 was constructed (Fig. 1). The $P$. infestans niaA gene is located on an internal 3.6-kb Sst I-fragment. This fragment, and an overlapping 8.5-kb HindIII-fragment, were subcloned into pTZ19 $\mathrm{U}$ resulting in the plasmids pNiaA-S and $\mathrm{pNiaA}-\mathrm{H}$, respectively. 
$\lambda$ nia2

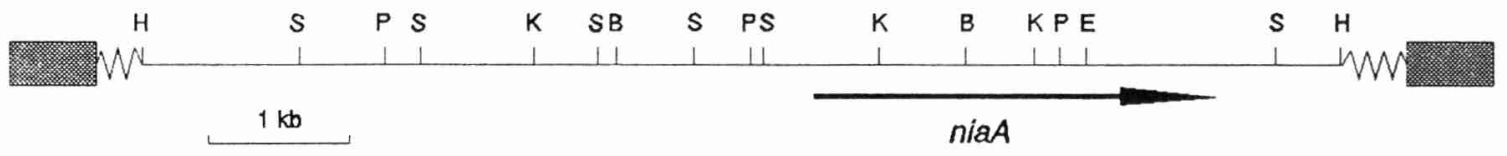

Fig. 1 Partial restriction map of the $\lambda$ nia 2 clone containing a full length copy of the $P$. infestans niaA gene. The arrow indicates the position of the coding sequence. $H=H i n d I I I ; S=S s t \mathrm{I} ; P=P s t \mathrm{I}$; $K=K p n \mathrm{I} ; B=B a m \mathrm{HI} ; E=E c o \mathrm{RI}$

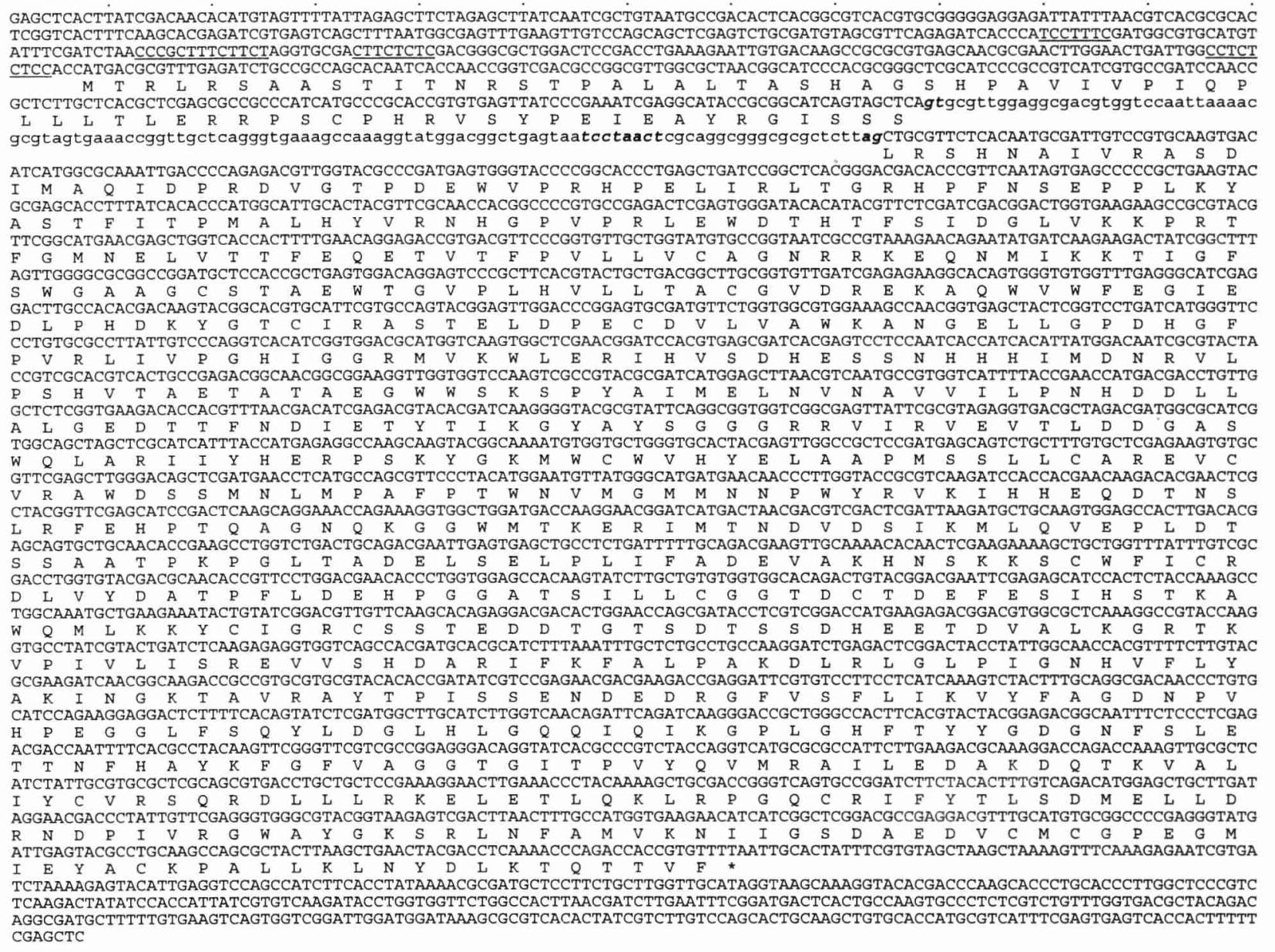

Fig. 2 Nucleotide sequence of the $P$. infestans niaA gene and the deduced amino-acid sequence of the NR protein. Position +1 is the first nucleotide of the ATG start codon. The CT-rich regions in the promoter are underlined. Lower case letters indicate the 115-bp intron with the intron boundary nucleotides and the branch point consensus in bold italics. The nucleotide sequence data reported will appear in the EMBL, GenBank and DDBJ Nucleotide Sequence Databases under the accession number U14405

\section{Structure of the $P$. infestans niaA gene}

To enable sequencing of the entire niaA gene, overlapping restriction fragments from $\mathrm{pNiaA}-\mathrm{S}$ were subcloned into pTZ19 U. Computer analysis of the nt sequence of the 3607-bp Sst I-fragment (as shown in Fig. 2) revealed a large continuous ORF which has significant regions of homology to the deduced amino-acid sequence of several other
NR-encoding genes. However, this ORF does not contain an initiation codon at the $5^{\prime}$ end. Upstream of this ORF a putative intron of $115 \mathrm{bp}$ is present and this intron is preceded by a smaller ORF encoding 67 aa with an initiation codon at the $5^{\prime}$ end. When the intron is removed a single ORF of 2706 nt with a coding capacity of 902 aa is found. The length of NR in other organisms is in the same range.

The putative intron begins with the nt sequence GTGCGT and ends with TAG which exactly matches the consensus sequences for $5^{\prime}$ and $3^{\prime}$ intron splice sites in filamentous fungi (GTPuNGPy and PyAG, respectively; Unkles 1992). The putative intron contains a 7-bp sequence, TCCTAAC, which is nearly identical tô the yeâst branch point consensus sequence TACTAAC. This sequence is known to be necessary for intron splicing and is specifically required for lariat formation. The TCCTAAC sequence in niaA is located at $23 \mathrm{bp}$ from the $3^{\prime}$ splice junc- 
tion which is consistent with the average location of branch point consensus sequences in filamentous fungi (Unkles 1992).

Analysis of the $367 \mathrm{nt}$ upstream of the ATG start codon revealed that this region lacks the consensus "core promoter' sequences TATAAA and CAAT, as well as the consensus sequence for the transcription initiation of oomycete genes, GCTCATTPyPyNCAWTTT (in which W is A or T; Pieterse et al. 1994). However, the upstream region contains some $\mathrm{CT}$-rich regions which are commonly found in the vicinity of the transcription initiation sites of filamentous fungal genes and are thought to be important for determining the position of transcription initiation (Unkles 1992). The nt sequence surrounding the translation start codon (CCACCATG) follows the Kozak consensus sequence for translation initiation (Kozak 1984). In the promoter region of the $P$. infestans niaA gene no striking homology with promoters from other nia genes is detectable. The $3^{\prime}$ non-coding region lacks identifiable motifs for transcript processing. Although some short AT-rich stretches occur, no clear AATAAA polyadenylation signal is present.

Comparison of $P$. infestans NR with that of other organisms

In order to compare the predicted $P$. infestans NR aa sequence with other NRs, the aa sequences were aligned by computer and the alignment was refined by eye for maximum homology (Fig. 3). The overall aa sequence of $P$. infestans NR is fairly similar to the NR sequences of other filamentous fungi and plants. The similarity scores range from $58 \%$ to $63 \%$ and the highest degree of similarity is found with Arabidopsis thaliana NR.

NRs contain three functional domains which are required for enzyme activity, i.e., the molybdenum cofactor domain, the heme domain and the FAD domain (Crawford et al. 1988). This so-called three-redox-centre protein is thought to have evolved from gene fusions between sequences coding for one-redox-centre proteins. Examples of the latter are rat liver sulphite oxidase (molybdenumcofactor-containing protein; Crawford et al. 1988), bovine liver cytochrome b5 (heme-binding protein; Ozols and Strittmatter 1969) and human NADH-cytochrome $b 5$ reductase (FAD-containing protein; Yubisui et al. 1984). The molybdenum cofactor domain in $P$. infestans NR is positioned in the N-terminal part of the protein. Two short peptides from sulphite oxidase show significant homology to amino-acid sequences $103-117$ (47\% identity) and 255-283 (48\% identity). The precise extent of this domain is unknown. The heme domain of $P$. infestans NR is located at amino-acid positions 535-611. This region shows $42 \%$ identity to the bovine liver cytochrome $b 5$ catalytic domain. The histidine residues at positions 572 and 595 are conserved in all NR sequences as well as in all members of the cytochrome $b 5$ superfamily (Guiard and Lederer 1979) in which they are considered to function as heme-ligands. Amino acids 634-902 show 41\% identity to the catalytic domain of human NADH-cytochrome $b 5$ reductase indicating that the FAD domain is situated at the C-terminal part of the protein. The lysine residue at position 710 and the cysteine residue at position 874, both of which are essential in cytochrome $b 5$ reductase (Hackett et al. 1986), are conserved in all NR sequences and are thought to be binding sites for NADPH. The peptide sequences representing the three domains are located in relatively highly conserved regions of the NR protein.

Nitrate reductase in $P$. infestans is encoded by a single-copy gene

On a genomic Southern blot, a probe derived from the coding region of the niaA gene hybridized to single DNA fragments in lanes containing $P$. infestans DNA digested with EcoRI, HindIII, KpnI, PstI and SstI (Fig. 4). The sizes of the hybridizing HindIII-, KpnI-, PstI- and SstI-fragments correspond to the sizes of the fragments in $\lambda$ nia2. In the BamHI digest, two fragments of 2.1 and $20 \mathrm{~kb}$ in length hybridize. The 1.1-kb KpnI fragment which was used as a probe, has an internal $\mathrm{Bam} \mathrm{HI}$ restriction site. The $2.1-\mathrm{kb}$ $B a m H I$ fragment coincides with the 2.1-kb Bam HI fragment in $\lambda$ nia2. Neither the size of the hybridizing $20-\mathrm{kb}$ $B a m \mathrm{HI}$ fragment nor that of the 19-kb EcoRI fragment can be verified as they are not completely represented in $\lambda$ nia 2 . These data demonstrate that the $P$. infestans genome contains a single copy of the niaA gene.

To determine whether the $P$. infestans niaA gene is transcribed, expression of the niaA gene was analyzed by northern-blot hybridization. The blot contained total RNA isolated from mycelium which was grown for 5 days in liquid Henniger synthetic medium containing a high concentration of $\mathrm{NaNO}_{3}(48 \mathrm{mM})$ and no ammonium, and total RNA isolated from mycelium grown on liquid Henniger synthetic medium with $48 \mathrm{mM}\left(\mathrm{NH}_{4}\right)_{2} \mathrm{SO}_{4}$ and no nitrate. After hybridization with the niaA probe a single transcript of approximately $3200 \mathrm{nt}$ was detected (Fig. 5a). The length of the niaA mRNA is in agreement with the length calculated from the nt sequence. The niaA mRNA was present in mycelium which was grown in $\mathrm{NaNO}_{3}$-containing medium but not in mycelium grown in medium supplemented with ammonium. Hybridization of the same blot

Fig. 3 Comparison of the predicted amino-acid sequence of $P$. infestans NR with the NRs of four other filamentous fungi, i.e., Ustilago maydis (Banks et al. 1993), Fusarium oxysporum (Diolez et al. 1993), Aspergillus niger (Unkles et al. 1992) and Neurospora crassa (Okamoto et al. 1991), and two plants, i.e., Arabidopsis thaliana (Crawford et al. 1988) and Lycopersicon esculentum (Daniel-Vedele et al. 1989). Identical amino-acids are indicated by shaded dots. Spaces introduced for optimal alignment are indicated by a dash $(-)$. In the line directly above the $P$. infestans sequence, amino-acid residues which are identical and similar in all seven NRs are indicated by asterisks and dots, respectively. The consensus sequences for the molybdenum cofactor domain at position $103-117$ and 255-283, the heme domain at position 535-611, and the FAD domain at position 634-902 are shown in bold italics. Arrows $(\Uparrow)$ indicate conserved functionally essential residues 
P.infestans

U.maydis

F.oxysporum

A.niger

N.crassa

A. thaliana

L.esculentu

作 .T-VTE--- TLLQQ--ERI PNS--

IQPLLLTLERRPSCPHRVSY

PEI IEAYRG ISSSL

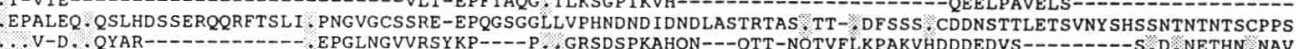

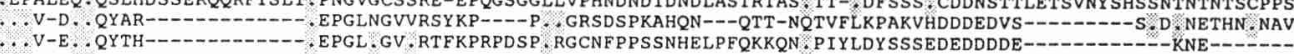

$103 \pitchfork$ \LINSQRPFNAEPPP $\$ 117$

P. infestans U.maydis F.oxysporum A.niger

N.crassa

L.esculentum
RSHNAIVRASDIMAQ-I-DPR-----DVGTPDEWVPRHPELIRLTGRHPFNSEPPLK--YASTFITPPMALHYVRNHGPVP

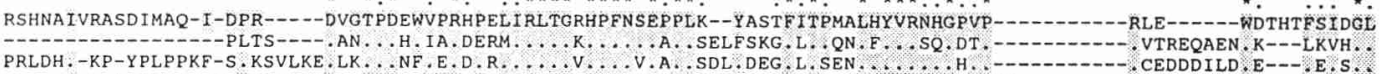

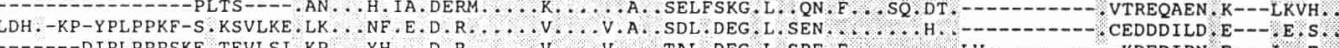
PITSSSLKPAYPLPPS. YYKEM RKSNAE YYKEM. RKSNAELEPSVL $\ldots, \ldots$
-YVQM.KKGKTELEPS.H.T.
P.infestans U.maydis F.oxysporum A.niger A. thaliana L.esculentum

P. infestans U.maydis . oxysporum A.niger N.Crassa A. thaliana

VKKPRTFGMNE-LVTTFEQ-ETVTFPVLLVCAGNRRKEONMIKKTIGFSWGAAGCSTAEWTGVPLHULLTACGVDPEK ${ }^{\star} .^{\star \star} \cdot{ }^{\star \star}$ .EQEVELSIKD- . KEK, SYS--HPOTIT -

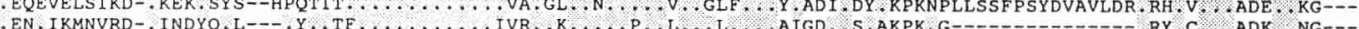
E..LVLNFRDI. EH. LKISVR. - MDA-SKWDNV.Y ..T . . . . . . . . . . VLR.SK . . . . . G. L . . . L . . . . G.SEI.ARAKPLTK. GGG -

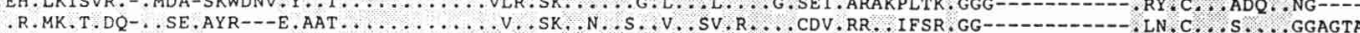

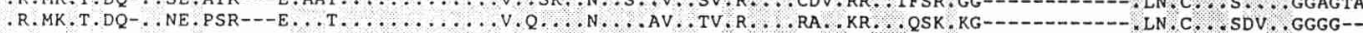

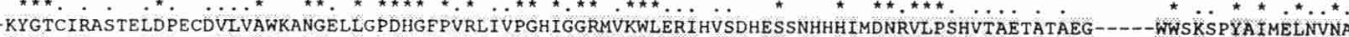

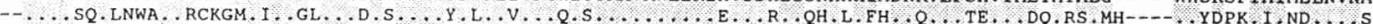

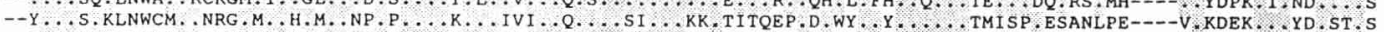

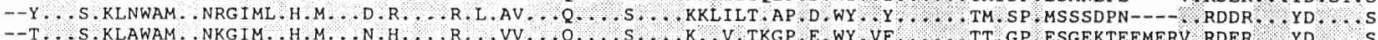

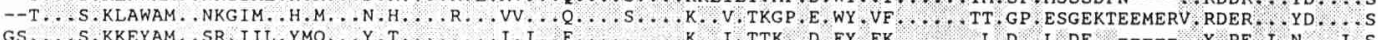

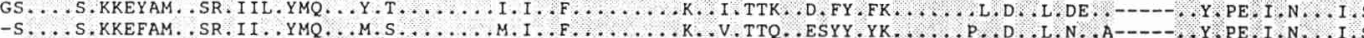

P.infestans U.maydis F.oxysporum A.niger A.crassa A. thaliana L.esculentum

P. infestan U.maydis F.oxysporum A.niger N.crassa

A. thaliana

. infestans U.maydis F.oxysporum F.niger

A. thaliana

A. thaliana

. infestan F.oxysporum A.niger A.thalian L.esculentum

P. infestans $U$. maydis

.oxysporu A. niger N.crassa

A. thaliana

L.esculentum

P. infestans U.maydis F.oxysporum A.niger N. crassa A. thaliana (
VVILPNHDDLLALGEDTTFNDIETYTIIKGYAYSGGGRRVIRVEVTLDDGASWQLARI I IXHERPSKYGKM

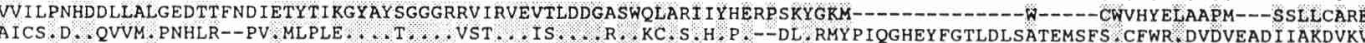
.

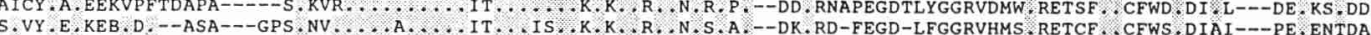

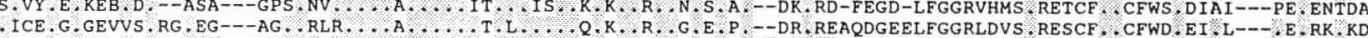

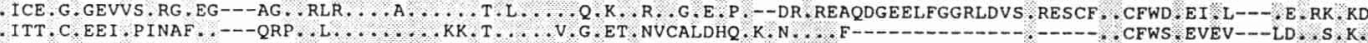
. ITT. C. EEI. PINAW . .--QRP . . LR. . . . . . . KK. T. . . . . . . G. ET. SVCTLDHP. K, T. . . . Y -

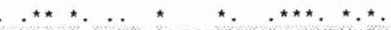

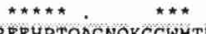
ERIMTNDVDSIKMLQVEPLDTSSAATPKPGL

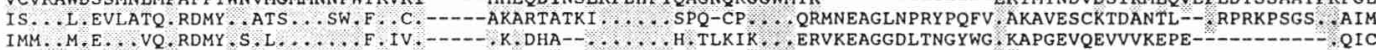

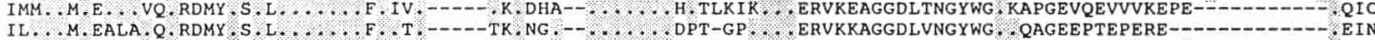

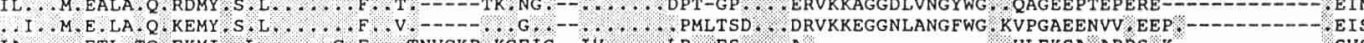

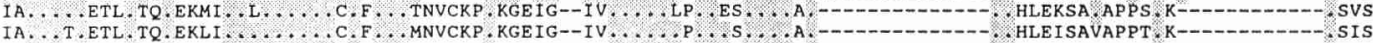

$535 \star S K A V K Y Y T L E Q I E R H N--S K-S T W L I L H Y K V Y D L T K F L E E H P G G E E V L R E Q A G G D-A T E D F E D V G H S T D A R E L S K T F I I G E L \star 611$

TADELSELPL IFADEVA-KHN--SKKSCWFICRDLVYDATPFLDEHFGGATSILLCGGTD-CTDEFESI-HSTKAWQMLKKXCIGRCSSTEDDTGTSD-TSSDHE- -- -

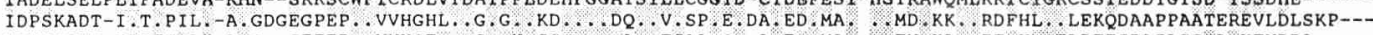

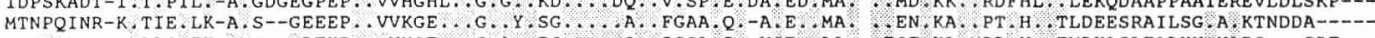

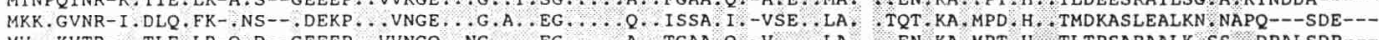

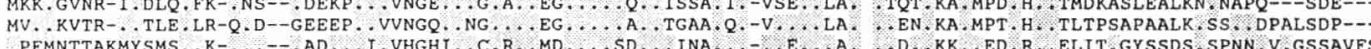

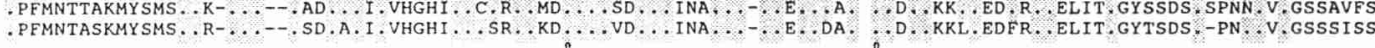

634 \$FQRSTPAITLESPDIKYPLRLIDREI ISHDTRRFRFALPSPQHILGLPVGHIYL----SARIDGNLVVRPYTPISSDDD--KGFVDLVIKVYFKDT---HP-

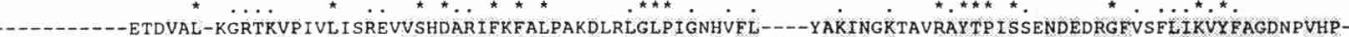
TRE

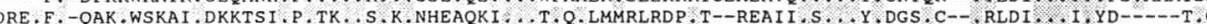

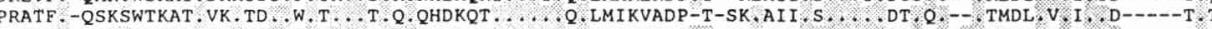

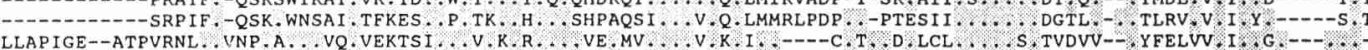

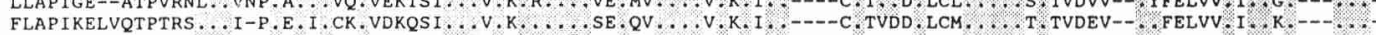

KFPNGGQM SQYLESMQIGDTIEF-----RGPSGLLVYQGKGKFAIRPDKKSNPIIRTVK-SVGMIAGGTGITPMLQVIRAIMKD------PDDHTVCHLLFANQTEK

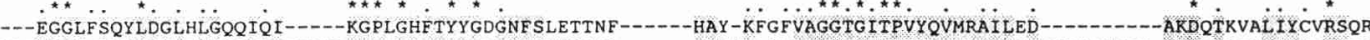

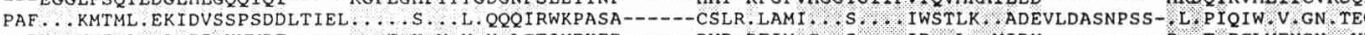

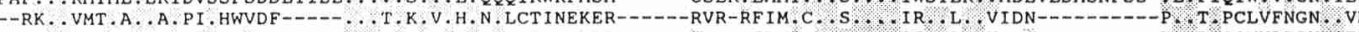

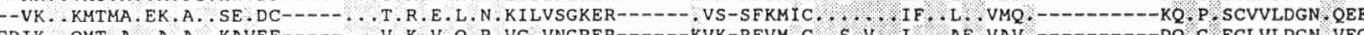

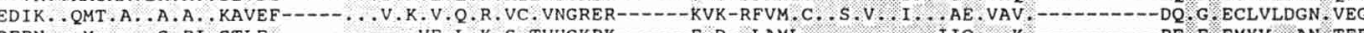

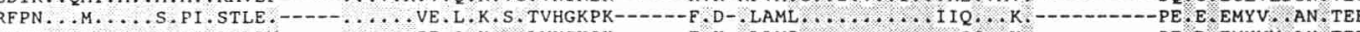

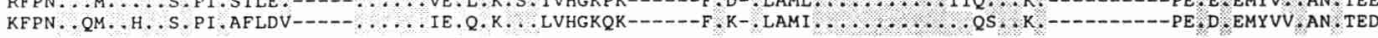

DILLRPELEEL--RNKHSAREKLWYTL------DRA-PE--AWDYGQGFVNEEMIRDH--LPPPEEEPLVLN-------CGPPPMTQYACLP-NLD--HVGHPTERCFVF 902

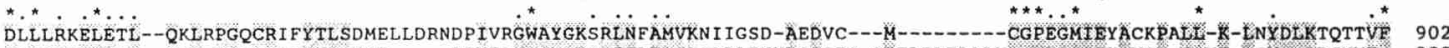
.I. I. E..DA.--SR. -K.NLKVWHV. .NCT-----PENEAN, SM. RG-ISLP. SLGAPATNHRQSCFG-GDELEDTLALV....PP.-EK, VSD-G.NE-.GW. .QRCVVF. 908 .I.CME ...E. E--AAN. SR. .VVNA..------NPPPE. NGL.GFV.Q.L.PEYMDLPK.-S--GEGDE----LLLV. . PP.V-K.VEASF. --GMGFK-SDDFVF. 906

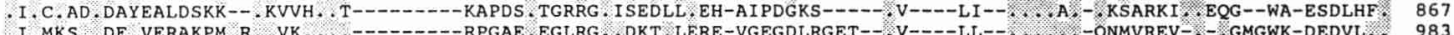

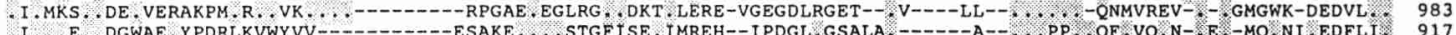

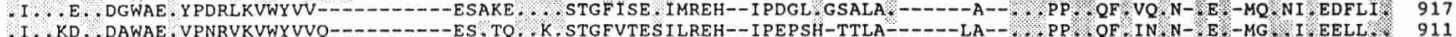




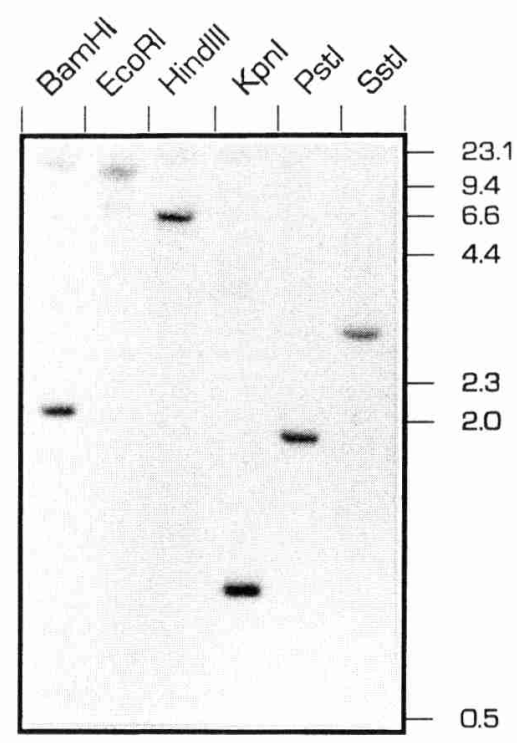

Fig. 4 Autoradiograph of a Southern blot containing genomic DNA of $P$. infestans digested with various restriction enzymes (as indicated) and hybridized with a 1.1-kb KpnI fragment from the coding region of niaA gene. Molecular-size markers are indicated in $\mathrm{kb}$

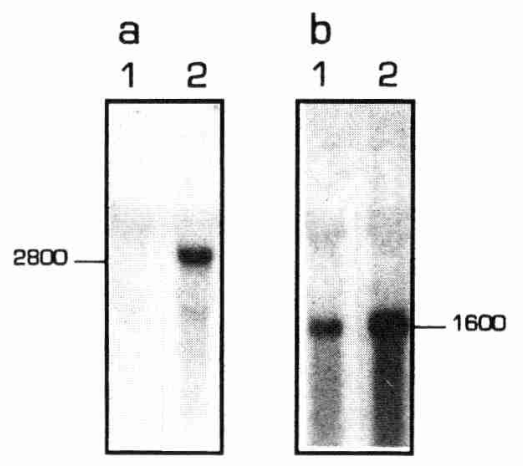

Fig. 5 a Autoradiograph of a $\mathrm{N}=$ northern-blot containing total RNA isolated from a $P$. infestans mycelium grown in liquid synthetic Henniger medium with $48 \mathrm{mM}\left(\mathrm{NH}_{4}\right)_{2} \mathrm{SO}_{4}$ (1) or $48 \mathrm{mM} \mathrm{NaNO}_{3}$ (2) as a nitrogen source and hybridized with a $2.2-\mathrm{kb} \mathrm{NcoI}$ fragment from the coding region of the niaA gene. b Autoradiograph of the same blot which, after de-probing, was hybridized with a probe derived from the $P$. infestans actin gene, act $A$

with an actin probe demonstrated that there was sufficient RNA present on the blot (Fig. 5b). It can thus be concluded that the niaA gene in $P$. infestans is a transcriptionally active gene and that expression of the niaA gene is dependent on the nitrogen source provided in the medium.

Transcriptional activation of the niaA promoter and other oomycete promoters in A. nidulans

NR genes from various fungi can complement NR deficiency in A. nidulans. Conversely, the niaD gene of $A$. nidulans, can complement NR-deficient strains of several other ascomycetous fungi (Daboussi et al. 1989). The en- zyme is strongly conserved through evolution and, as shown above, NR encoded by the $P$. infestans niaA gene contains all the conserved domains which are essential for enzyme activity. It is anticipated, therefore, that the enzyme derived from the $P$. infestans niaA gene should be able to complement a NR-deficient strain of another species. Therefore we used the P. infestans niaA gene as a model gene to test whether or not the promoter of an oomycete gene can be activated in the non-oomycete $A$. nidulans.

Plasmid pNiaA-H, which contains the intact $P$. infestans niaA gene with $4.4 \mathrm{~kb}$ upstream of and $0.8 \mathrm{~kb}$ downstream from the niaA coding region, was transformed to ANGW1103, a NR-deficient $A$. nidulans strain. In a control experiment plasmid pSTA10 (Unkles et al. 1989a) containing the A. niger niaD gene was transformed to the same recipient strain. Numerous pSTA10 transformants grew on medium containing $50 \mathrm{mM}$ of $\mathrm{NaNO}_{3}$ as a sole nitrogen source demonstrating that the A. niger niaD gene can functionally complement the deletion in ANGW 1103. However, upon transformation with pNiaA-H no colonies appeared on selective medium and apparently in this case complementation did not occur. Co-transformation of ANGW 1103 with pAN8-1 in combination with pSTA10 or pNiaA-H resulted in many phleomycin-resistant transformants. When the percentage co-transformation was determined by analyzing growth of the transformants on minimal medium with $50 \mathrm{mM} \mathrm{NaNO}$ as a sole nitrogen source it appeared that co-transformation of pSTA10 occurred in $37 \%$ of the cases (Table 1). Integration of pNiaA-H in the pAN8-1 + pNiaA-H co-transformation experiment was determined by Southern-blot analyses and it appeared that from ten randomly selected transformants at least four were co-transformed with pNiaA-H (Table 1). All co-transformants contained full-length copies of the $P$. infestans niaA gene integrated in the genome (data not shown). Nevertheless, these stable transformants were not able to complement the nia ${ }^{-}$ phenotype. These results strongly suggest that the $P$. infestans niaA gene is not expressed in A. nidulans. However, it can not be ruled out that the protein is not functional.

Two other oomycete promoters, the ham 34 and the $u b i 3 R$ gene promoters, were tested for activity in A. nidulans. The ham 34 gene of $B$. lactucae is highly expressed in germinating spores (Judelson and Michelmore 1990) and its promoter is frequently used to drive the expression of antibiotic genes in chimaeric constructs employed for transformation of $P$. infestans (Judelson et al. 1991, 1992, 1993). The $P$. infestans ubi3R gene is expressed in mycelium grown in vitro and at a ten-fold higher level during colonization of potato leaves (Pieterse et al. 1991). Plasmids containing the ham 34 promoter and the $u b i 3 R$ promoter fused to the $\beta$-glucuronidase (GUS) reporter gene, pHAMT35G and pPUB-HAM respectively (Judelson et al. 1992, 1993), were transformed to A. nidulans. Subsequently, transient expression was determined by measuring GUS activity. Compared to the control plasmid pNOM102 in which the GUS gene is driven by the $A$. $n i$ dulans gpd promoter (Roberts et al. 1989), pHAMT35G and pPUB-HAM gave hardly any GUS activity in the tran- 
Table 1 Co-transformation frequencies

\begin{tabular}{lll}
\hline Plasmids & \multicolumn{2}{l}{ Percentage co-transformation determined by } \\
\cline { 2 - 3 } & $\begin{array}{l}\text { Growth on } \mathrm{NaNO}_{3}^{-} \\
\text {containing medium }\end{array}$ & $\begin{array}{l}\text { Southern-blot } \\
\text { analysis }\end{array}$ \\
\hline pAN8-1 + pSTA10 & $37(52)$ & ND $^{\text {c, d }}$ \\
pAN8-1 + pNiaA-H & $0(47)$ & $40(10)$
\end{tabular}

\footnotetext{
${ }^{a}$ Indicated in parentheses are the number of phleomycin-resistant colonies that were tested for growth on medium containing $\mathrm{NaNO}_{3}$ as a sole nitrogen source

${ }^{\mathrm{b}}$ Indicated in parentheses are the number of phleomycin-resistant colonies of which the DNA was analyzed by Southern-blot hybridizations

${ }^{\mathrm{c}} \mathrm{ND}=$ not determined

${ }^{\mathrm{d}}$ From the 19 transformants that grew on medium containing $\mathrm{NaNO}_{3}$ as a sole nitrogen source, two were analyzed by Southern-blot hybridizations. Both transformants appeared to contain one or more complete copies of plasmid pSTA10
}

Table 2 Comparison of promoter activities in transient expression assays in A. nidulans

\begin{tabular}{llc}
\hline Plasmid $^{\mathrm{a}}$ & Source of promoter fused to GUS & GUS activity \\
\hline pNOM102 $^{\mathrm{c}}$ & gpd from A. nidulans & 100 \\
pHAMT35G $^{\mathrm{d}}$ & ham34 from B. lactucae & 4 \\
pPOB-HAM $^{\mathrm{e}}$ & ubi3R from P. infestans & 2 \\
pCF181 & ecp2 from C. fulvum $^{\mathrm{g}}$ & 40 \\
pMOG18 & 35S from CaMV & 36 \\
\hline
\end{tabular}

\footnotetext{
a The plasmids contain the indicated promoters fused to the coding region (1870 bp) of the GUS reporter gene encoding $\beta$-glucuronidase

${ }^{\mathrm{b}}$ Expressed as relative activity in percentages compared to pNOM102 (100\%)

${ }^{\mathrm{c}}$ Roberts et al. 1989

dudelson et al. 1992

e Judelson and Michelmore 1990

${ }^{f}$ Judelson et al. 1993

${ }^{g}$ Pieterse et al. 1991

${ }^{\mathrm{h}}$ Wubben et al. 1994

Sijmons et al. 1990
}

sient-expression assay (Table 2). Although the activity of the ham 34 promoter was consistently a fraction higher than that of the $u b i 3 R$ promoter, it never reached more than $4 \%$ of the activity of the A. nidulans gpd promoter. In contrast, the promoters of the ecp 2 gene of Cladosporium fulvum, a plant pathogenic ascomycete, and the CaMV $35 S$ gene, a very active plant virus promoter, have significantly higher activities than the two oomycete gene promoters (Table 2 ). These data show that the two oomycete gene promoters are not functional in A. nidulans.

\section{Discussion}

In this paper we describe the isolation and characterization of the P. infestans niaA gene encoding NR. The gene contains an ORF encoding a protein of 902 amino-acids. Com- parison of the amino-acid sequence with other NRs shows that, except for the amino-terminal sequence, the overall structure of NR proteins is highly conserved among species. Based on comparisons with amino-acid sequences from one-redox-centre proteins, the approximate boundaries of the molybdenum cofactor domain, the heme domain and the FAD domain were identified. All conserved residues which have been shown to be functionally essential are present in $P$. infestans NR.

The niaA gene is the first known $P$. infestans gene which appears to have an intron. All other $P$. infestans genes studied to-date, ten in total, lack introns (Pieterse et al. 1991, 1993, 1994; Unkles et al. 1991; Moon et al. 1992). So far, only one other oomycetous gene with introns has been described, i.e., the Phytophthora parasitica trp1 gene (Karlovsky and Prell 1991).

$P$. infestans contains a single copy of the niaA gene per haploid genome. If, as in other filamentous fungi or plants, inactivation of this gene results in insensitivity to chlorate, the niaA gene could be a potentially powerful tool to trap mobile elements in P. infestans (Grandbastien et al. 1989; Daboussi et al. 1992). The niaA gene is transcriptionally active and expression is dependent on the nitrogen source present in the medium. In the absence of sufficient levels of favourable nitrogen sources, such as ammonium, the niaA gene is expressed. In the presence of ammonium expression of the niaA gene is not detectable. Whether regulation of the P. infestans niaA gene is based on nitrogen catabolite repression and nitrate induction, as has been observed in other fungi (Marzluf et al. 1992), needs to be investigated. The hexameric sequence TAGATA, which is present in the promoters of several nitrogen-regulated structural genes and functions in a similar manner as the binding site for the NIT-2 trans-acting regulatory protein in Neurospora crassa (Fu and Marzluf 1990), is not found in the promoter region of the niaA gene. This suggests that in filamentous fungi the mechanism of regulation of expression of nitrogen-regulated structural genes in not conserved and might be one of the reasons that the $P$. infestans niaA gene is not functional in A. nidulans.

The NR enzyme has been strongly conserved throughout evolution, and since NR encoded by the $P$. infestans niaA gene contains all the conserved domains which are essential for enzyme activity the enzyme derived from the $P$. infestans niaA gene ought to be able to complement a NR-deficient strain of another species. Nevertheless, in our experiments such complementation did not occur. This may be due to the possibility that the protein is not functional in A. nidulans. However, the most likely explanation for this observation is that the enzyme is absent simply because the $P$. infestans niaA gene is not activated in A. nidulans. The latter explanation is supported by the finding that two other oomycete gene promoters, those of $u b i 3 R$ and ham 34, are not functional in A. nidulans and leads to the general conclusion that oomycete gene promoters are not recognized in A. nidulans. Similar observations were reported by Judelson et al. (1992) who were unable to find activation of oomycete gene promoters in Saccharomyces cerevisiae, $N$. crassa and Ustilago maydis. This suggests 
hat oomycete genes need specialized components for transcription which are absent in non-oomycete fungi.

Acknowledgements Plasmids pPUB-HAM and PHAMT35G were kindly provided by H. J. Judelson, pCF 181 by J. P. Wubben, pMOG 18 by Mogen International, pNOM-102 by I. N. Roberts and pSTA 10 by S. E. Unkles. A. nidulans stain ANGW1103 was a gift from T. Goossen.

\section{References}

Banks GR, Holden DW, Kanuga N, Shelton P, Spanos A (1993) Gene 131:69-78

Cove DJ (1966) Biochem Biophys Acta 113:51-56

Crawford NM, Smith M, Bellissimo D, Davis RW (1988) Proc Natl Acad Sci USA 85:5006-5010

Daboussi MJ, Djeballi A, Gerlinger C, Blaiseau PL, Bouvier I, Cassan M, Lebrun MH, Parisot D, Brygoo Y (1989) Curr Genet $15: 453-456$

Daboussi MJ, Langin T, Brygoo Y (1992) Mol Gen Genet 232:12-16

Daniel-Vedele F, Dorbe MF, Caboche M, Rouzé P (1989) Gene $85: 371-380$

Devereux J, Haeberli P, Smithies O (1984) Nucleic Acids Res 12:387-395

Diolez A, Langin T, Gerlinger C, Brygoo Y, Daboussi MJ (1993) Gene 131:61-67

Feinberg, Vogelstein (1983) Anal Biochem 132:6-13

Fu YH, Marzluf GA (1990) Proc Natl Acad Sci USA 87:5331-5335

Gallagher SR (1992) Quantitation of GUS activity by fluorometry. In: Gallagher SR (ed) GUS protocols. Academic Press, San Diego, pp 47-59

Guiard B, Lederer F (1979) J Mol Biol 135:639-650

Grandbastien MA, Spielman A, Caboche M (1989) Nature $337: 376-380$

Hackett CS, Novoa WB, Ozols J, Strittmatter P (1986) J Biol Chem 261:9854-9857

Henniger H (1959) Phytopatholog Zeitschrift 34:285-306

Judelson HS, Michelmore RW (1990) Mol Plant-Microbe Interact $3: 225-232$

Judelson HS, Tyler BM, Michelmore RW (1991) Mol Plant-Microbe Interact 4:602-607

Judelson HS, Tyler BM, Michelmore RW (1992) Mol Gen Genet 234:138-146

Judelson HS, Dudler R, Pieterse CMJ, Unkles SE, Michelmore RW (1993) Gene 133:63-69

Karlovsky P. Prell HH (1991) Gene 109: 211-218

Kozak M (1984) Nucleic Acids Res 12:857-872

Mattern IE, Punt P (1988) Fungal Genet Newslett 35:25
Marzluf GA, Kanaan M, Fu YH (1992) In: Stahl U, Tudzynski P (eds) Molecular biology of filamentous fungi. VCH, Weinhei New York, pp 153-166

Moon RP, Unkles SE, Duncan JM, Hawkins, AR, Kinghorn JR (1992) Plant Mol Biol 1209-1211

Okamoto PM, Fu YH, Marzluf GA (1991) Mol Gen Genet $227: 213-223$

Ozols J, Strittmatter P (1969) J Biol Chem 244:6617-6618

Pieterse CMJ, Risseeuw EP, Davidse LC (1991) Plant Mol Biol 17:799-811

Pieterse CMJ, Riach MBR, Bleker T, van den Berg-Velthuis GCM, Govers F (1993a) Physiol Mol Plant Pathol 43:69-79

Pieterse CMJ, Verbakel HM, Hoek Spaans J, Davidse LC, Govers F (1993b) Mol Plant-Microbe Interact 6:164-172

Pieterse CMJ, van West P, Verbakel HM, Brassé, PWHM, van den Berg-Velthuis GCM, Govers F (1994) Gene 128:67-77

Roberts IN, Oliver RP, Punt, PJ, van den Hondel CAMJJ (1989) Curr Genet 15:177-180

Sambrook J, Fritch EF, Maniatis T (1989) Molecular cloning: a laboratory manual. Cold Spring Harbor Laboratory, Cold Spring Harbor, New York

Sanger F, Nicklen S, Coulson AR (1977) Proc Natl Acad Sci USA 74:5463-5467

Sijmons PC, Dekker BMM, Schrammeijer B, Verwoerd TC, van den Elzen PJM, Hoekema A (1990) Bio/Technology 8:217-221

Tomsett AB, Cove DJ (1979). Genet Res 34:19-32

Unkles SE (1992) Gene organization in industrial filamenous fungi. In: Kinghorn JR, Turner G (eds) Applied molecular genetics of filamenous fungi. Blackie Academic and Professional, Glasgow, pp 28-53

Unkles SE, Campbell EI, Carrez D, Grieve C, Contreras R, van den Hondel CAMJJ, Kinghorn JR (1989a) Gene 78:157-166

Unkles SE, Campbell EI, de Ruijter-Jacobs YMJT, Broekhuijsen MP, Macro JA, Carrez D, Grieve C, Contreras R, van den Hondel CAMJJ, Kinghorn JR (1989b) Mol Gen Genet 218:99-104

Unkles SE, Moon RP, Hawkins AR, Duncan JM, Kinghorn JR (1991) Gene 100:105-112

Unkles SE, Campbell EI, Punt PJ, Hawker KL, Contreras R, Hawkins AR, van den Hondel, CAMJJ, Kinghorn JR (1992) Gene 111:149-155

Wernars K, Goosen T, Wennekes LMJ, Visser J, Bos CJ, van den Broek HWJ, van Gorcom RFM, van den Hondel CAMJJ, Pouwels PH (1985) Curr Genet 9:361-368

Whitehead MP, Unkles SE, Ramsden M, Campbell EI, Gurr SJ, Spence, D, van den Hondel CAMJJ, Contreras, R, Kinghorn, JR (1989) Mol Gen Genet 216:408-411

Wubben JP, Joosten MHAJ, de Wit PJGM (1994) Mol Plant-Microbe Interact 7:516-524

Yubisui T, Miyata T, Iwanaga S, Tamura M, Yoshida S, Takeshita M, Nakajima H (1984) J Biochem 96:579-582 